Article

\title{
A Comparative Study of the Sintering Behavior of Pure and Manganese-Substituted Hydroxyapatite
}

\author{
Michael Zilm ${ }^{1}$, Seamus D. Thomson ${ }^{2}$ and Mei Wei ${ }^{1, *}$ \\ ${ }^{1}$ Department of Materials Science and Engineering, University of Connecticut, 97 North Eagleville Rd, \\ Unit 3136, Storrs, CT 06269, USA; E-Mail: michael.zilm@uconn.edu \\ 2 Department of Aerospace, Mechanical and Mechatronic Engineering, J07 University of Sydney, \\ University of Sydney, Sydney, NSW 2006, Australia; E-Mail: stho6915@uni.sydney.edu.au \\ * Author to whom correspondence should be addressed; E-Mail: meiwei@engr.uconn.edu; \\ Tel.: +1-860-486-9253; Fax: +1-860-486-4745.
}

Academic Editor: Rafael Luque

Received: 12 July 2015 / Accepted: 14 September 2015 / Published: 18 September 2015

\begin{abstract}
Hydroxyapatite (HA) is a widely studied biomaterial for its similar chemical composition to bone and its osteoconductive properties. The crystal structure of HA is flexible, allowing for a wide range of substitutions which can alter bioactivity, biodegradation, and mechanical properties of the substituted apatite. The thermal stability of a substituted apatite is an indication of its biodegradation in vivo. In this study, we investigated the thermal stability and mechanical properties of manganese-substituted hydroxyapatite (MnHA) as it is reported that manganese can enhance cell attachment compared to pure HA. Pure HA and MnHA pellets were sintered over the following temperature ranges: 900 to $1300{ }^{\circ} \mathrm{C}$ and 700 to $1300{ }^{\circ} \mathrm{C}$ respectively. The sintered pellets were characterized via density measurements, mechanical testing, X-ray diffraction, and field emission electron microscopy. It was found that MnHA was less stable than HA decomposing around $800{ }^{\circ} \mathrm{C}$ compared to $1200{ }^{\circ} \mathrm{C}$ for HA. The flexural strength of MnHA was weaker than HA due to the decomposition of MnHA at a significantly lower temperature of $800{ }^{\circ} \mathrm{C}$ compared to $1100{ }^{\circ} \mathrm{C}$ for HA. The low thermal stability of MnHA suggests that a faster in vivo dissolution rate compared to pure $\mathrm{HA}$ is expected.
\end{abstract}

Keywords: hydroxyapatite; ion substitution; sintering behavior 


\section{Introduction}

Hydroxyapatite (HA) is an inorganic constituent of natural bone, which has been extensively studied for its biocompatible and osteo-regenerative properties, serving a scaffold for modern bone graft substitutes [1-3]. As such, HA is widely used for coating orthopedic implants where a strong interface with bone is required and as a bone cement for craniofacial repair [4,5]. However, HA is brittle in nature and has a slow in vivo degradation rate which limits its applications to coatings for orthopedic implants [2,6-8]. To overcome these issues, HA may be densified through sintering to improve mechanical strength and or through ionic substitutions to enhance bioactivity and mechanical strength [7-15].

The pressing and sintering of HA have been known to improve its ultimate compressive strength and toughness [7,15]. Sintering can occur as low as $800{ }^{\circ} \mathrm{C}$ with the final sintered density serving as a function of the particle size distribution and agglomeration characteristics of the starting HA powder $[9,10]$. For temperatures greater than $700{ }^{\circ} \mathrm{C}$, HA begins to decompose into different phases such as tricalcium phosphate $(\mathrm{TCP})$, calcium oxide $(\mathrm{CaO})$ and water $\left(\mathrm{H}_{2} \mathrm{O}\right)$ [16]. Overall, the presence of TCP in HA scaffolds affects the strength, density, pore size, and degradation rate of HA [15,17]. TCP degrades faster than HA in vivo.

Stoichiometric $\mathrm{HA}$ has been generally accepted as having a hexagonal $\mathrm{P}_{3} / \mathrm{m}$ structure with chemical formula $\mathrm{Ca}_{10}\left(\mathrm{PO}_{4}\right)_{6}(\mathrm{OH})_{2}$ to denote the chemical composition and symmetry composing the crystal unit cell $[16,18]$. This apatite structure is flexible, which can be substituted by various elements, such as $\mathrm{Na}, \mathrm{Mg}, \mathrm{K}, \mathrm{Sr}, \mathrm{Zn}, \mathrm{Ba}, \mathrm{Cu}, \mathrm{Al}, \mathrm{Fe}, \mathrm{F}, \mathrm{Cl}$, and carbonate ions [11,13,15]. Alteration of the chemical formula of HA through substitutions can alter its bioactivity, which is a similar approach to modify the bioactivity of bioglasses [8].

In improving the bioactivity of a material it is critical for the material to support cell attachment and the extracellular matrix which contains bioactive factors to induce regeneration [19]. When manganese is substituted into the HA lattice (MnHA) the MnHA has the attractive feature of improving cellular adhesion [20-24]. Manganese (Mn) is an essential trace metal found in all tissues and is required for normal amino acid, lipid, protein, and carbohydrate metabolism [25,26]. Mn plays a crucial role in cellular signaling, especially in the activation of integrins; receptors that mediate cellular interactions between the extracellular matrix and ligands on cell surfaces [12,27]. The ligand affinity increases for integrins in the presence of $\mathrm{Mn}$ ions, promoting cellular adhesion and possibly having the ability to enhance osteogenesis [27,28]. The development of new tissue engineered scaffolds that provide mechanical support as well as repair and regeneration of damaged or diseased bone may readily benefit from the introduction of Mn into current HA scaffolds [2].

MnHA has been previously synthesized through various wet synthesis techniques [12,28-38]. Many of these studies examine the stability of MnHA through varying the wt $\%$ of manganese or the calcination temperature. Mayer et al. attempted to incorporate manganese up to $6 \mathrm{wt} \%$ via wet synthesis which decomposed at $600{ }^{\circ} \mathrm{C}$ into $\beta$-TCP $[12,34,35]$. Other attempts to incorporate up to $5 \mathrm{wt} \%$ manganese followed by calcination at $800{ }^{\circ} \mathrm{C}$, by Paluszkiewicz et al. resulted in phase purity up to $1 \mathrm{wt} \%$ manganese [36]. The phase stability of MnHA at varying manganese wt $\%$ is well understood but there are few studies on the effect of manganese substitution and mechanical properties. Ramesh et al. produced MnHA through a wet milling technique and observed a decrease in the Vickers 
hardness of sintered MnHA up to 1 wt \% relate density [39]. Herein we report a facile one-step room temperature ion exchange method to synthesize MnHA, as well as a systematic study of the sintering behavior, microstructural evolution and flexural strength over a series of temperatures to determine the suitability of MnHA for biomedical applications. The relationship between mechanical properties, microstructure and phases helps identify suitable biomedical applications for pure MnHA and its decomposition products.

\section{Results and Discussion}

\subsection{Results}

\subsubsection{Powder Characterization}

SPEX-milled as-synthesized HA and MnHA powders were characterized with TEM for particle size analysis. Micrographs of HA and MnHA powders are depicted in Figure 1. Both powders have morphologies of small rods with an average aspect ratio of $2.6 \pm 0.8$ for HA and $2.4 \pm 0.7$ for MnHA particles. HA particles $(n=151)$ have an average length of $35 \pm 11 \mathrm{~nm}$ and an average width of $14 \pm 3 \mathrm{~nm}$. Similar to HA, MnHA particles $(n=155)$ have an average length of $36 \pm 11 \mathrm{~nm}$ and a width of $16 \pm 4 \mathrm{~nm}$.

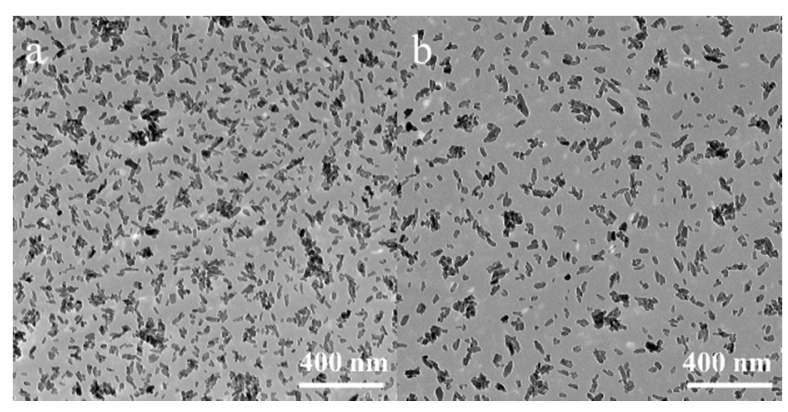

Figure 1. TEM micrographs of SPEX-milled Hydroxyapatite (HA) (a) and manganese-substituted hydroxyapatite (MnHA) (b) powders.

\subsubsection{XRD Characterization}

Powder diffraction patterns of the as-synthesized and heat-treated HA are depicted in Figure 2. The as-synthesized material displays broad peaks and is identified as HA based on JCPDF 9-432. At $800{ }^{\circ} \mathrm{C}$, the observed peaks become more intense with no extraneous peaks. The indexed peaks for HA continue to increase in intensity up to $1200{ }^{\circ} \mathrm{C}$ and decrease at $1300{ }^{\circ} \mathrm{C}$. Decomposition of HA is observed around $900{ }^{\circ} \mathrm{C}$ with the emergence of calcium oxide $(\mathrm{CaO})$ and $\beta$-tricalcium phosphate $\left(\beta\right.$-TCP) peaks indexed at $27.8^{\circ}$ and $29.68^{\circ} 2 \theta$ for $\beta$-TCP and $37.4^{\circ}$ for $\mathrm{CaO}$. At $1300{ }^{\circ} \mathrm{C}$, HA decomposes further and $\alpha$-TCP peaks started to emerge. 


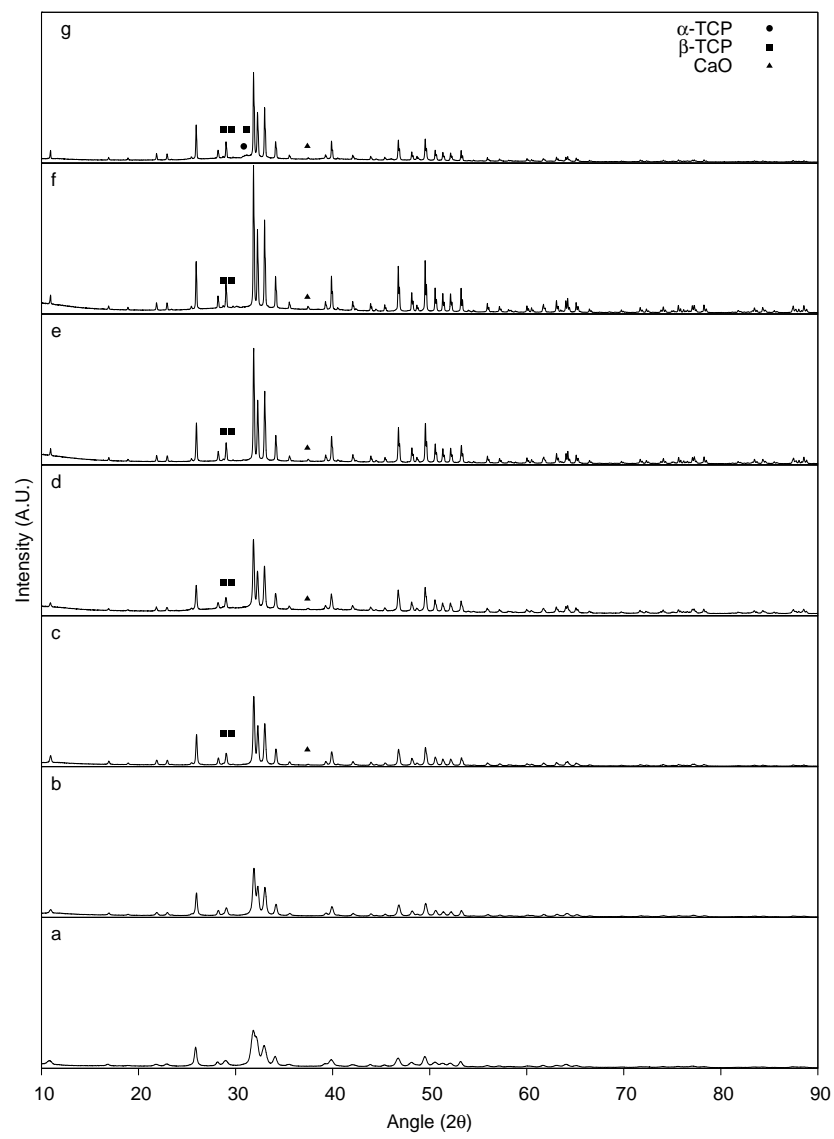

Figure 2. Powder XRD pattern of as-synthesized HA (a) and HA heat treated at: $800{ }^{\circ} \mathrm{C}$ (b); $900{ }^{\circ} \mathrm{C}(\mathbf{c}) ; 1000{ }^{\circ} \mathrm{C}(\mathbf{d}) ; 1100{ }^{\circ} \mathrm{C}(\mathbf{e}) ; 1200{ }^{\circ} \mathrm{C}(\mathbf{f})$; and $1300{ }^{\circ} \mathrm{C}(\mathbf{g})$. Non-labeled peaks correspond to observed reflections from pure HA.

In comparison to the as-synthesized HA, the as-synthesized MnHA exhibits the same powder diffraction pattern indicative of a pure Mn substituted HA, as shown in Figure 3. Unlike HA, MnHA start to decompose to $\beta$-TCP and manganese oxide $\left(\mathrm{Mn}_{3} \mathrm{O}_{4}\right)$ at a temperature as low as $800{ }^{\circ} \mathrm{C}$, Figure 3, with continuous decomposition at higher temperatures. At $1200{ }^{\circ} \mathrm{C}$ further decomposition into $\alpha$-TCP is observed producing a mixture of $\alpha$-TCP, $\beta$-TCP, and $\mathrm{Mn}_{3} \mathrm{O}_{4}$.

\subsubsection{Density and Biaxial Flexural Strength}

After sintering but prior to density measurements and mechanical testing the physical appearance of the sintered pellets was observed. Sintered HA pellets underwent shrinkage at all temperatures but maintained their white appearance. In contrast, the MnHA pellets not only underwent shrinkage but also resulted in a change in physical appearance which is depicted in Figure 4. The initial green pellet is light pink but after sintering at $700{ }^{\circ} \mathrm{C}$ turns dark blue. Subsequent sintering temperatures resulted in further color transitions with gray pellets observed at $800{ }^{\circ} \mathrm{C}$, yellow from 900 to $1000{ }^{\circ} \mathrm{C}$, reddish brown at $1100{ }^{\circ} \mathrm{C}$, and black from 1200 to $1300^{\circ} \mathrm{C}$. 


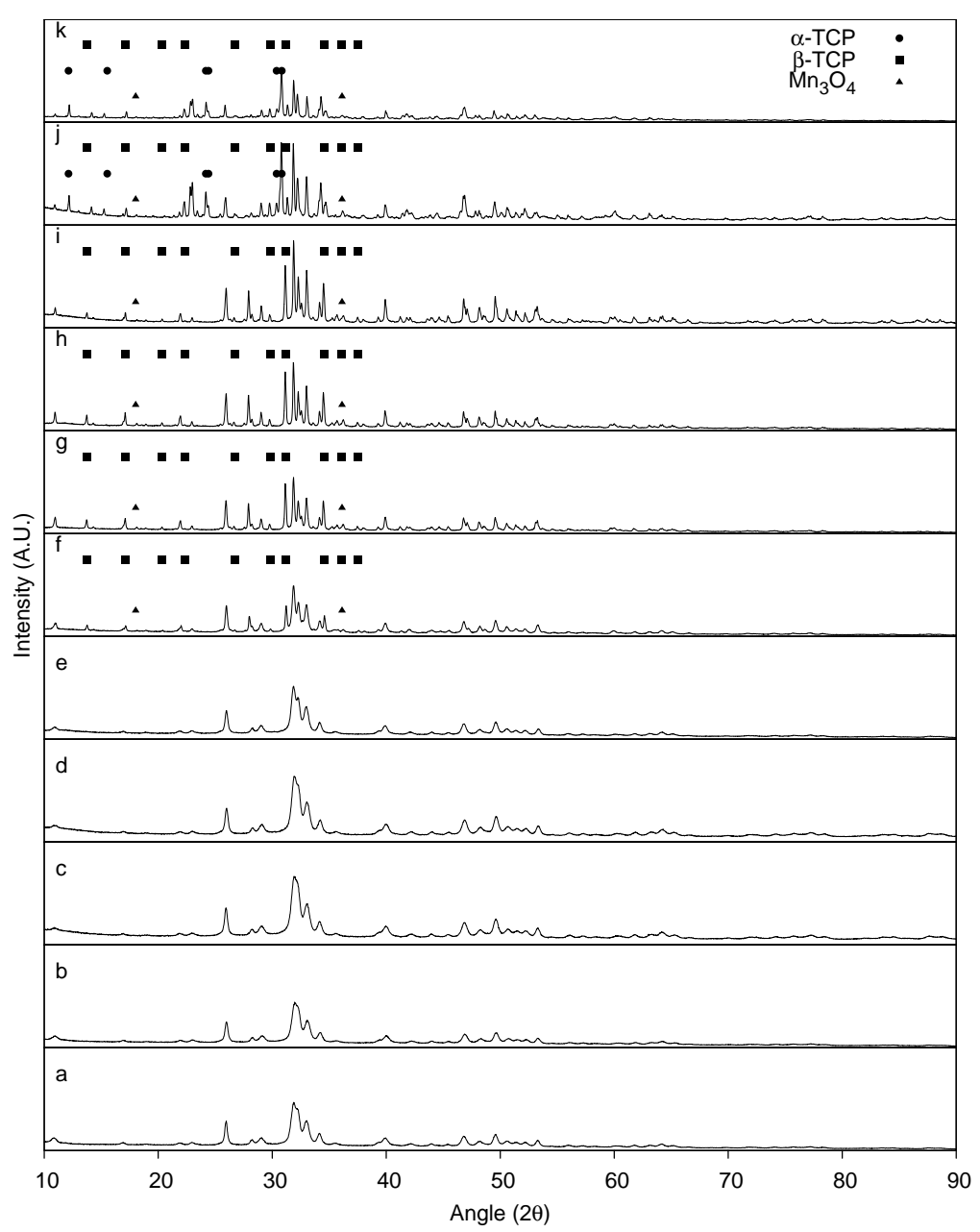

Figure 3. Powder XRD pattern of as-synthesized MnHA (a) and MnHA heat-treated at: $400{ }^{\circ} \mathrm{C}(\mathbf{b}) ; 500{ }^{\circ} \mathrm{C}(\mathbf{c}) ; 600{ }^{\circ} \mathrm{C}(\mathbf{d}) ; 700{ }^{\circ} \mathrm{C}(\mathbf{e}) ; 800{ }^{\circ} \mathrm{C}(\mathbf{f}) ; 900{ }^{\circ} \mathrm{C}(\mathbf{g}) ; 1000{ }^{\circ} \mathrm{C}(\mathbf{h}) ; 1100{ }^{\circ} \mathrm{C}$ (i); $1200{ }^{\circ} \mathrm{C}(\mathbf{j})$; and $1300{ }^{\circ} \mathrm{C}(\mathbf{k})$. Non-labeled peaks correspond to observed reflections from pure HA.

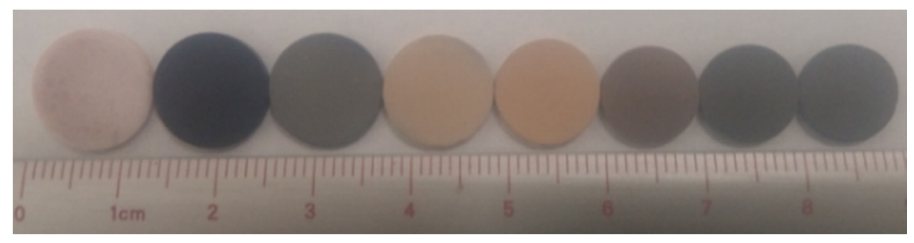

Figure 4. Photograph of green and sintered MnHA pellets. From left to right: green MnHA followed by MnHA heat-treated at $700-1300{ }^{\circ} \mathrm{C}$ at $100{ }^{\circ} \mathrm{C}$ increments. The pellet size also decreases from left to right.

The initial green densities, after cold isostatic pressing, and final sintered densities are summarized in Table 1 along with the percent densified. Green bodies of HA have an average density around $1.8 \mathrm{~g} / \mathrm{cm}^{3}$, while MnHA have a density around $1.65 \mathrm{~g} / \mathrm{cm}^{3}$. The final densities of HA and MnHA pellets at various soaking temperatures are depicted in Figure 5. A one way ANOVA analysis was performed to determine statistically significant differences. There was a statistically significant difference $(p<0.05)$ in HA densities $\left(p=5.93 \times 10^{-16}\right)$ and MnHA densities $\left(p=5.38 \times 10^{-35}\right)$ over the studied temperature 
ranges. After sintering at $900{ }^{\circ} \mathrm{C}$ the HA pellets start to densify followed by increased densification upon sintering at $1000{ }^{\circ} \mathrm{C}$. Within the temperature range of 1000 to $1300{ }^{\circ} \mathrm{C}$, HA pellets continue to densify with increasing temperature until $1300{ }^{\circ} \mathrm{C}$, where a maximum density of $2.99 \mathrm{~g} / \mathrm{cm}^{3}$ is achieved. For MnHA specimens the sintered density continuously increases over the studied temperature range which is reflected in the percent densified. An abrupt increase in density is observed from 900 to $1000{ }^{\circ} \mathrm{C}$ corresponding to a density of 2.02 and $2.53 \mathrm{~g} / \mathrm{cm}^{3}$, respectively. From 1000 to $1300{ }^{\circ} \mathrm{C}$ the density continues to increases and reaches a maximum density of $2.68 \mathrm{~g} / \mathrm{cm}^{3}$ at $1300{ }^{\circ} \mathrm{C}$.

Table 1. Average density values of green and sintered bodies and percent densification for each studied temperature point.

\begin{tabular}{ccccccc}
\hline $\begin{array}{c}\text { Temperature } \\
\left({ }^{\circ} \mathbf{C}\right)\end{array}$ & $\begin{array}{c}\text { Average Green Density } \\
\left(\mathbf{g} / \mathbf{c m}^{\mathbf{3}}\right)\end{array}$ & \multicolumn{2}{c}{$\begin{array}{c}\text { Average Sintered Density } \\
\left(\mathbf{g} / \mathbf{c m}^{\mathbf{3}}\right)\end{array}$} & \multicolumn{2}{c}{$\begin{array}{c}\text { Average Percent } \\
\text { Densified }\end{array}$} \\
\cline { 2 - 7 } & $\mathbf{H A}$ & $\mathbf{M n H A}$ & $\mathbf{H A}$ & $\mathbf{M n H A}$ & HA & MnHA \\
\hline 800 & - & 1.78 & - & 1.95 & - & 9.4 \\
900 & 1.80 & 1.76 & 2.68 & 2.08 & 49.4 & 18.2 \\
1000 & 1.81 & 1.58 & 2.94 & 2.02 & 62.0 & 28.1 \\
1100 & 1.83 & 1.62 & 2.97 & 2.53 & 61.9 & 56.4 \\
1200 & 1.80 & 1.59 & 2.98 & 2.59 & 65.4 & 62.9 \\
1300 & 1.81 & 1.58 & 2.99 & 2.68 & 65.5 & 70.2 \\
\hline
\end{tabular}

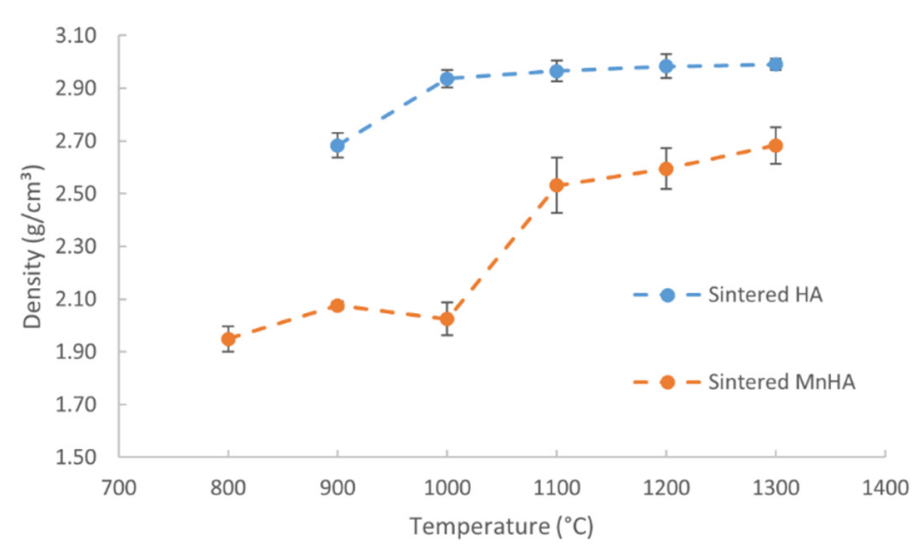

Figure 5. Densities of sintered HA and MnHA pellets as a function of temperature. Average densities are plotted \pm standard deviation $(n \geqslant 4)$.

Due to the compressive and bending forces typically exerted on bones, the flexural strength of the sintered pellets were evaluated by a modulus of rupture (M.O.R) test, and the mechanical properties are depicted in Figure 6. A one way ANOVA was performed to determine statistically significant differences. There was a statistically significant difference $(p<0.05)$ in M.O.R between HA $\left(p=1.33 \times 10^{-7}\right)$ and MnHA $\left(p=4.4 \times 10^{-13}\right)$ over the studied temperature ranges. The M.O.R of sintered HA pellets ranges from $23 \mathrm{MPa}$ at $1300{ }^{\circ} \mathrm{C}$ to $78 \mathrm{MPa}$ at $1000{ }^{\circ} \mathrm{C}$. Initially the M.O.R increases from 900 to $1000{ }^{\circ} \mathrm{C}$ and then continuously decreases from 1000 to $1300{ }^{\circ} \mathrm{C}$. Unlike HA, the M.O.R. values of the sintered MnHA continuously increase over the temperature range of 800 to $1300{ }^{\circ} \mathrm{C}$ ranging from $18 \mathrm{MPa}$ at $800{ }^{\circ} \mathrm{C}$ to 
$64 \mathrm{MPa}$ at $1300{ }^{\circ} \mathrm{C}$. From 800 to $1000{ }^{\circ} \mathrm{C}$ there is a small gradual increase in the M.O.R values followed by a rapid increase over the range of 1000 to $1200{ }^{\circ} \mathrm{C}$ with a small increase from 1200 to $1300{ }^{\circ} \mathrm{C}$.

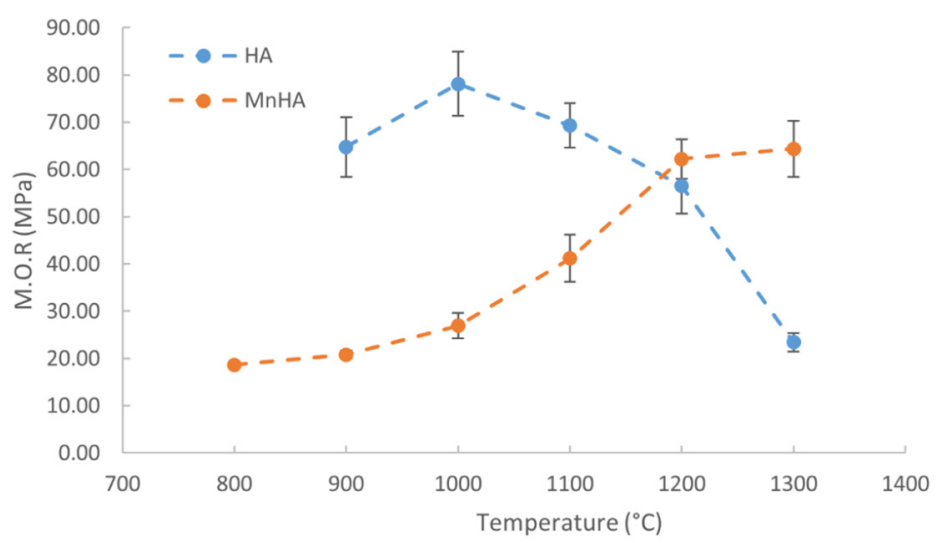

Figure 6. Mechanical properties of sintered HA and MnHA pellets as a function of temperature. Average M.O.R values are plotted \pm standard error $(n \geqslant 4)$.

\subsubsection{FESEM Characterization}

The sintering behavior of heat-treated HA and MnHA specimens was further investigated using FESEM. Fractured surfaces of sintered HA pellets are depicted in Figure 7. Specimens heat treated at $900{ }^{\circ} \mathrm{C}$ exhibit signs of sintering where the HA particles have fused together and the pores between particles have started to round, but there are still a large number of pores present in specimens. At $1000{ }^{\circ} \mathrm{C}$, the HA specimens have sintered completely with few rounded pores present. At temperatures greater than $1000^{\circ} \mathrm{C}$, grain growth is observed with increasing temperature. Pores remain over the range of 1000 to $1300{ }^{\circ} \mathrm{C}$ with a rounded morphology and grow in size with increasing temperature.

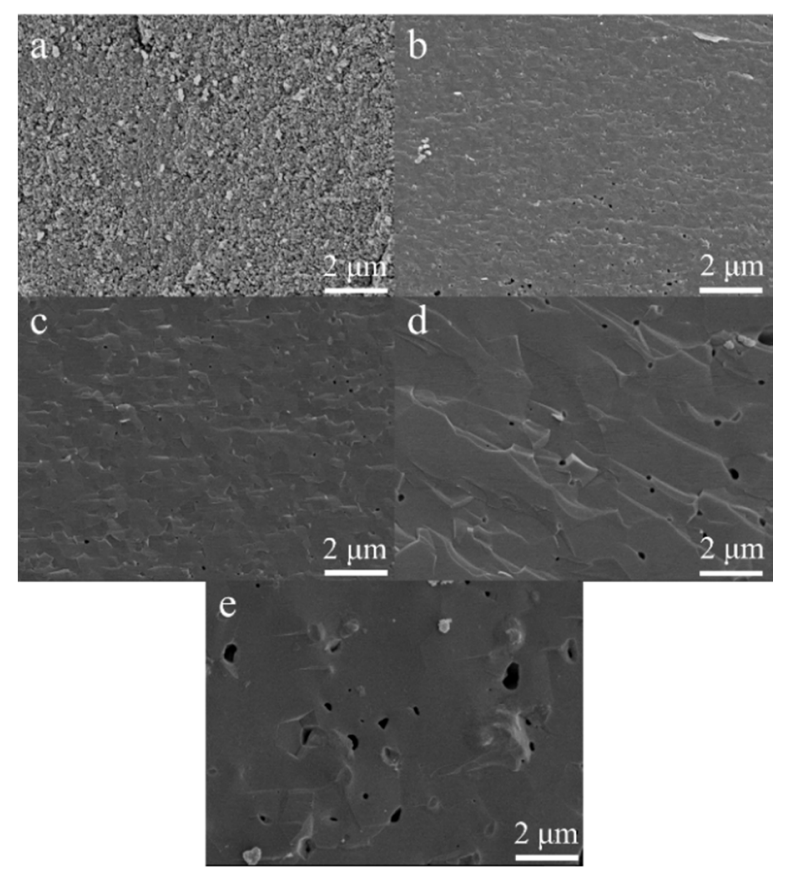

Figure 7. Cross sections of sintered HA pellets at $900{ }^{\circ} \mathrm{C}(\mathbf{a}) ; 1000{ }^{\circ} \mathrm{C}(\mathbf{b}) ; 1100{ }^{\circ} \mathrm{C}(\mathbf{c})$; $1200{ }^{\circ} \mathrm{C}(\mathbf{d})$; and $1300{ }^{\circ} \mathrm{C}(\mathbf{e})$. Micrographs $(\mathbf{a}-\mathbf{e})$ were taken at $10,000 \times$ magnification. 
Fracture surfaces of heat-treated MnHA pellets are depicted in Figure 8 . At $700{ }^{\circ} \mathrm{C}$ the particles of the green body are identifiable and there is no indication of particles fusing at this temperature. Unlike $\mathrm{HA}, \mathrm{MnHA}$ starts to sinter at a temperature as low as $800{ }^{\circ} \mathrm{C}$, where individual particles have started to fuse together, but the overall structure still demonstrates a porous network. The onset of decomposition of MnHA also occurred at $800{ }^{\circ} \mathrm{C}$. The pellets continue to sinter with increasing temperature and the porosity of the sintered body slowly decreases. Significant porosity increase is present at $1200{ }^{\circ} \mathrm{C}$, which is $100{ }^{\circ} \mathrm{C}$ lower than that observed in HA sintering.

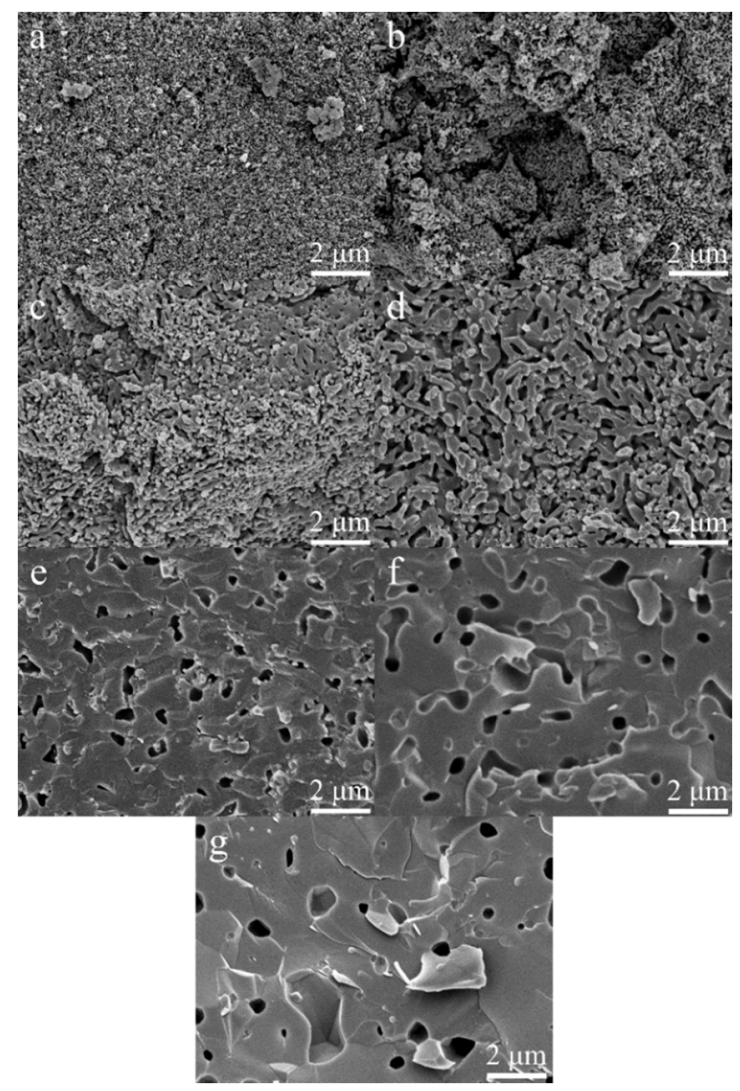

Figure 8. Cross sections of sintered MnHA pellets at $700{ }^{\circ} \mathrm{C}(\mathbf{a}) ; 800{ }^{\circ} \mathrm{C}(\mathbf{b}) ; 900{ }^{\circ} \mathrm{C}(\mathbf{c})$; $1000{ }^{\circ} \mathrm{C}(\mathbf{d}) ; 1100{ }^{\circ} \mathrm{C}(\mathbf{e}) ; 1200{ }^{\circ} \mathrm{C}(\mathbf{f})$; and $1300{ }^{\circ} \mathrm{C}(\mathbf{g})$. Micrographs (a-g) were taken at $10,000 \times$ magnification.

Since the sintering of HA specimens was complete at $1000{ }^{\circ} \mathrm{C}$, FESEM was used to for grain size analysis over the temperature range from 1000 to $1300{ }^{\circ} \mathrm{C}$. Figure 9 shows polished and etched surfaces of HA sintered bodies. The measured grain size was $110,305,765 \mathrm{~nm}$, and $1.8 \mu \mathrm{m}$ from 1000 to $1300{ }^{\circ} \mathrm{C}$. A relationship between the M.O.R and the inverse square root of grain size of sintered HA bodies is depicted in Figure 10. The M.O.R increases with decreasing grain size following a linear relationship from 1000 to $1200{ }^{\circ} \mathrm{C}$, which follows the classical Hall-Petch relationship with the following relation

$$
\text { M.O.R }=\tau_{o}+k d^{-\frac{1}{2}}
$$

where $\tau_{\mathrm{o}}$ and $k$ are material constants and $d$ is the average grain size. 


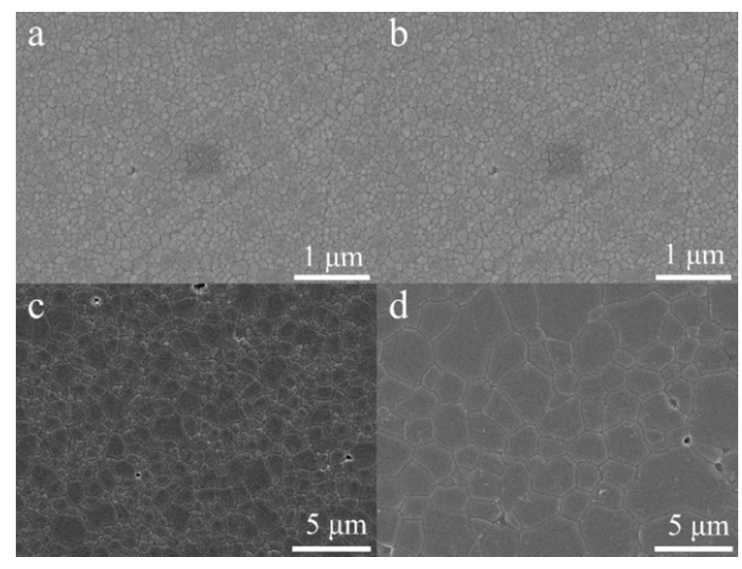

Figure 9. FESEM images of the etched surface of HA pellets sintered at $1000{ }^{\circ} \mathrm{C}(\mathbf{a})$; $1100{ }^{\circ} \mathrm{C}(\mathbf{b}) ; 1200{ }^{\circ} \mathrm{C}(\mathbf{c})$; and $1300{ }^{\circ} \mathrm{C}$ (d). Note the differences in magnification. Micrographs (a) and (b) were taken at 25,000×. Micrographs (c) and (d) were taken at $5000 \times$.

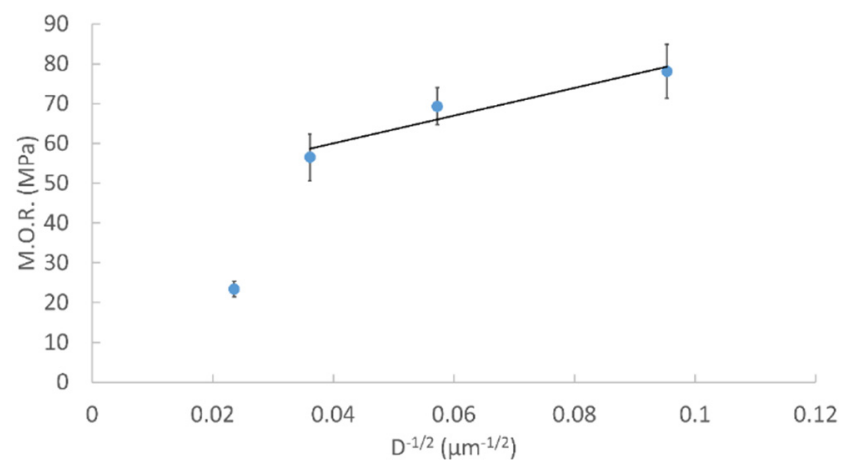

Figure 10. Modulus of rupture of HA as a function of the inverse square root of the grain size over the temperature range from 1000 to $1300{ }^{\circ} \mathrm{C}$.

\subsection{Discussion}

The ceramic phase of bone is a poorly crystalline phase of HA with numerous impurities which influence HA's thermal stability, and mechanical and bioactive properties. Pure HA is normally stable until $1350{ }^{\circ} \mathrm{C}$ before decomposing into calcium oxide $(\mathrm{CaO})$ and tricalcium phosphate (TCP) [40]. In the current study, the decomposition of the as-synthesized HA into $\mathrm{CaO}$ and $\beta$-TCP started at $900{ }^{\circ} \mathrm{C}$. HA with chemical impurities, such as carbonate, have been shown to degrade at temperatures as low as $800{ }^{\circ} \mathrm{C}$ [41]. The synthesis method used in this study was exposed to an ambient atmosphere which resulted in partial carbonation of the precipitated $\mathrm{HA}$, as previously reported [42]. As the temperature increases from 900 to $1200{ }^{\circ} \mathrm{C}$, the HA phase increases in crystallinity with temperature. A transition is observed at $1300{ }^{\circ} \mathrm{C}$, where the peak intensity of the HA phase decreases in intensity compared to $1200{ }^{\circ} \mathrm{C}$. The relative intensity between the decomposed phases $\beta$-TCP and $\mathrm{CaO}$ to HA is greater at $1300{ }^{\circ} \mathrm{C}$ compared to $1200{ }^{\circ} \mathrm{C}$ indicating that the decomposition of the HA phase increases with the sintering temperature.

The thermal stability of MnHA was investigated over the range of 400 to $1300{ }^{\circ} \mathrm{C}$. A larger temperature range than HA was selected since manganese oxides have been shown to undergo phase 
transitions as low as $400{ }^{\circ} \mathrm{C}$ [43]. The as-synthesized MnHA powder diffraction pattern matches the observed pattern for the as-synthesized HA indicating successful substitution of Mn into the HA lattice. The phase purity of MnHA is maintained up to $800{ }^{\circ} \mathrm{C}$ where significant decomposition into $\beta$-TCP and $\mathrm{Mn}_{3} \mathrm{O}_{4}$ has occurred. Upon further heating, MnHA decomposes into $\alpha$-TCP, $\beta$-TCP, and $\mathrm{Mn}_{3} \mathrm{O}_{4}$ at $1200{ }^{\circ} \mathrm{C}$; these phases remain present at $1300{ }^{\circ} \mathrm{C}$. The transformation of $\beta$-TCP to $\alpha$-TCP is typically observed around $1125^{\circ} \mathrm{C}$ [44].

The microstructure of HA and MnHA were investigated with FESEM over the temperature range studied for mechanical testing. Pure HA normally starts to sinter around $1000{ }^{\circ} \mathrm{C}$ [40], but in this study HA was observed to sinter at $900{ }^{\circ} \mathrm{C}$. HA nanorods with similar reported aspect ratios around 2.4 and an average length around $55 \mathrm{~nm}$ have been shown to start to sinter as low as $850{ }^{\circ} \mathrm{C}$ [45]. The sintering behavior at low temperatures resulted from surface defects such as $\mathrm{OH}^{-}$vacancies and vacancies created from the release of carbonate groups which lowers the activation energy for surface diffusion [45]. Proceeding from 900 to $1000{ }^{\circ} \mathrm{C}$ sintering has completed which is observed in the closure of the pores between particles and an increase in the sintered density which plateaus around $95 \%$ of the theoretical density $\left(3.156 \mathrm{~g} / \mathrm{cm}^{3}\right)$ over the rest of the studied temperature range. The grain size and pore size increase with the sintering temperature. The grains grow as part of the recrystallization and growth process, while the increase in pore size is a result of the dehydroxylation process of HA. At temperatures exceeding $800{ }^{\circ} \mathrm{C}$ HA starts to lose water; during this process pressure builds from water vapor and results in blowhole formation with larger blowholes at higher temperatures.

In the case of MnHA sintering occurred around $800{ }^{\circ} \mathrm{C}$, which coincided with the onset of decomposition. The decomposition of MnHA over the temperature range of 800 to $1000{ }^{\circ} \mathrm{C}$ results in a highly porous and interconnected structure which may be attributed to the counteracting processes of both sintering and dehyrdoxylation of HA. The overall porosity slowly decreases over this temperature range. The porosity significantly decreases at $1100^{\circ} \mathrm{C}$, which is reflected in the increase in densification. The pores have become isolated and are lager in size. A similar microstructure was observed at 1200 and $1300{ }^{\circ} \mathrm{C}$, but with less porosity and larger pores. The porosity over the range of 1100 to $1300{ }^{\circ} \mathrm{C}$ is related to the decomposition products of HA.

Interestingly over this temperature range the sintered densities increased slowly as seen in the percent densification, and the higher sintered density at $900{ }^{\circ} \mathrm{C}$ compared to $1000{ }^{\circ} \mathrm{C}$ is attributed to the greater initial green density of $900{ }^{\circ} \mathrm{C}$ specimens compared to $1000{ }^{\circ} \mathrm{C}$. The differences between these green densities were a result of variation in batch to batch processing of MnHA where the degree of agglomeration influences the final green density after pressing.

HA and MnHA display different densification and mechanical behavior as a function of temperature. The difference in densification behavior is a result of their discrepancy in thermal stability which influences the microstructure as discussed above. Meanwhile, the mechanical behavior is closely related to the microstructure of the material. HA pellets achieved a maximum M.O.R around $78 \mathrm{MPa}$, which compares favorably with the values reported in literature of bulk HA which range from 45 to $150 \mathrm{MPa}$ [7,46-54]. The wide range of reported values results from differences in processing and impurities. Hot isostatic pressing which results in a more homogenous microstructure and fewer defects was used by Boilet et al. and Raynaud et al. to achieve flexural strengths in excess of $100 \mathrm{MPa}[53,54]$. Kana et al. observed that carbonated HA has a lower flexural strength, $45 \mathrm{MPa}$, when compared to pure 
$\mathrm{HA}, 75 \mathrm{MPa}$ [51]. The literature values of flexural strength and the observed maximum M.O.R are also within the range of reported flexural moduli of natural bone which ranges from 35 to $283 \mathrm{MPa}$ [55].

The M.O.R shown in Figure 6 depicts that the M.O.R initially increases for HA peaking at $1000{ }^{\circ} \mathrm{C}$ and then decreases over the rest of the temperature range. The initial increase is a result of fewer pores from improved densification from 900 to $1000{ }^{\circ} \mathrm{C}$. After $1000{ }^{\circ} \mathrm{C}$ the M.O.R continuously decreases with increasing temperature. Three mechanisms may be attributed to the decreased M.O.R: (1) larger grains; (2) higher porosity and (3) more decomposition. Improved strength and hardness are observed in ceramics with smaller grains which provide more barriers to crack propagation compared to larger grains. Pores are sites of concentrated stress which reduces the stress need for crack initiation and propagation leading to premature failure. The decomposition process of HA results in pore formation and inhomogeneous microstructure which also reduce the overall strength. The main mechanism resulting in a decrease in the M.O.R is an increase in grain size from 1000 to $1200{ }^{\circ} \mathrm{C}$ which follows the classical Hall-Petch relation. A similar Hall-Petch relation was observed in the hardness of nanocrystalline HA sintered over the temperature range of 850 to $1200{ }^{\circ} \mathrm{C}$ with grain sizes ranging from 65 to $730 \mathrm{~nm}$ by Wang et al. [56]. At $1300{ }^{\circ} \mathrm{C}$ the M.O.R deviates from the Hall-Petch relation as a result of HA decomposition to TCP. The reduction in M.O.R is a result of increased grain size, porosity and pore size.

The increase in the M.O.R as a function of temperature for MnHA is attributed to the sintering behavior of the material, as MnHA densifies the degree of porosity decreases. At sintering temperatures lower than $1100{ }^{\circ} \mathrm{C}$, a highly porous and interconnected microstructure is observed. The large degree of porosity and the interconnectivity of the pores result in a fragile structure. The formation of a denser microstructure with isolated pores observed from 1100 to $1300{ }^{\circ} \mathrm{C}$ results in an increase in the M.O.R attributed to a reduction in porosity. The maximum M.O.R observed for MnHA is around $64 \mathrm{MPa}$ at $1300{ }^{\circ} \mathrm{C}$ which is lower than the maximum M.O.R observed for pure HA. Sintering at $1200{ }^{\circ} \mathrm{C}$, the HA phase has almost completely decomposed with $\alpha$-TCP, $\beta$-TCP, and $\mathrm{Mn}_{3} \mathrm{O}_{4}$ being the dominate phases. The flexural strength of $\beta$-TCP is weaker than natural bone and is often detrimental to the mechanical properties of HA when presents as an impurity [53,57]. The maximum observed M.O.R of MnHA of $64 \mathrm{MPa}$ compares favorably with literature values. Studies on the mechanical properties of metal substituted $\beta$-TCP and sintered laminate $\beta$-TCP have shown flexural strengths ranging from 20 to $160 \mathrm{MPa}[58,59]$. Despite the decomposition of MnHA to TCP, the fast degradation rate of TCP sometimes is a desirable property in many biomedical applications. TCP has been mixed with HA to produce tissue engineering scaffolds with accelerated degradation rate compared to pure HA scaffolds [60].

\section{Experimental Section}

\subsection{Materials}

The following materials were purchased from Acros Organics (Grand Island, NY, USA): Ammonium phosphate dibasic (99+\%), sulfuric acid (95\%-98\%), stearic acid (97\%), and potassium bromide (IR grade). Calcium nitrate (99+\%), manganese chloride tetrahydrate $(99+\%)$, and ammonium hydroxide $(29.45 \%)$ were purchased from Fisher Scientific (Pittsburh, PA, USA). 


\subsection{Hydroxyapatite and Manganese Hydroxyapatite Synthesis}

HA was synthesized via a wet chemical method. An aqueous solution of ammonium phosphate dibasic $(80 \mathrm{mM})$ was added drop-wise to an aqueous calcium nitrate solution $(225 \mathrm{mM})$ at room temperature with the calcium to phosphate ratio maintained at 1.667. Ammonium hydroxide was used to raise the $\mathrm{pH}$ of both solutions above 11 prior to mixing the two solutions. Once the two solutions were completely mixed, the temperature of the solution was raised to $95{ }^{\circ} \mathrm{C}$ for five hours, and then it was cooled to room temperature and aged for two days under constant stirring. The precipitates were collected via centrifugation and washed 3 times with de-ionized, 2 times with ethanol and vacuumed dried.

MnHA was synthesized through an ion-exchange procedure. A salt solution of $\mathrm{MnCl}_{2}$ was prepared at a concentration of $0.02 \mathrm{M}$ and the $\mathrm{pH}$ was adjusted to 2.7 with dilute sulfuric acid. Previously synthesized HA was immersed in the ion-exchange solution at $0.5 \mathrm{~g} / \mathrm{dL}$ and sonicated for one hour at room temperature with intermittent stirring. The ion-exchanged HA was collected by centrifugation, washed 3 times with DIW and then vacuumed dried.

The collected precipitates were ground with a mortar and pestle for $30 \mathrm{~min}$ into a fine powder. The resulting powders were then milled (SPEX 8000 Mixer/Mill, SPEX, Metuchen, NJ, USA) for 10 min in a steel canister with alumina mixing balls.

\subsection{Pellet Preparation and Sintering}

SPEX-milled HA and MnHA powders were uniaxially pressed into pellets using a bench top Carver press (Carver Model C). Green bodies were prepared by pressing $0.3 \mathrm{~g}$ of milled powder in a $13 \mathrm{~mm}$ steel die well lubricated with stearic acid and acetone at a pressure of $150 \mathrm{MPa}$ for $10 \mathrm{~s}$. To improve the final green densities of the green bodies, uniaxially pressed pellets were further compacted through cold isostatic pressing. Uniaxially pressed pellets were vacuumed sealed in latex bags and then cold isostatic pressed at $210 \mathrm{MPa}$ for $30 \mathrm{~s}$.

Pellets were sintered at various temperatures (900 to $1300{ }^{\circ} \mathrm{C}$ for HA specimens and $700-1300{ }^{\circ} \mathrm{C}$ for MnHA specimens at $100{ }^{\circ} \mathrm{C}$ intervals) in air with a soaking time of one hour in a chamber furnace (CM, 1610FL, Bloomfield, NJ, USA). Specimens were heated at a ramp rate of $15^{\circ} \mathrm{C} / \mathrm{min}$ to the soaking temperature and then cooled to room temperature at a rate of $15^{\circ} \mathrm{C} / \mathrm{min}$. A total of 10 pellets of $\mathrm{HA}$ or MnHA were sintered for each temperature point.

\subsection{Characterization}

The milled as-synthesized HA and MnHA powders were examined with a FEI Tecnai T12 S/TEM transmission electron microscope (TEM, FEI, Hillsboro, OR, USA). Powders were dispersed in ethanol via sonication and deposited onto a copper TEM grid with a carbon film.

As-synthesized HA and MnHA, along with sintered HA and MnHA specimens were assessed for phase purity using a Bruker D2 Phaser X-ray diffractometer (XRD, Bruker, Madison, WI, USA) with a copper target. Powder diffraction patterns were acquired over 2-theta ranging from $10-90^{\circ}$ with a step size of $0.02^{\circ}$ and a scan rate of $1.25 \mathrm{~s}$ per step. 
Density measurements were performed on the final green bodies and sintered pellets using Ohaus digital balance with an accuracy of $1 \mathrm{mg}$ and a caliper (Mitutoyo, Aurora, IL, USA) with an accuracy of $0.01 \mathrm{~mm}$. Pellet height and diameter were measured in triplicates for each pellet and the average diameter and height were used to calculate the pellet density.

A Tinius Olsen (150 KS model) was used to determine the biaxial flexural strength on sintered $13 \mathrm{~mm}$ pellets using a $1000 \mathrm{~N}$ load cell at a crosshead speed of $0.01 \mathrm{~mm} /$ minute. A pin-on-disc fixture set up was used according to ASTM F 394 [61]. The modulus of rupture was calculated by the following equations:

$$
S=0.2387 \frac{P(X-Y)}{d^{2}}
$$

where $S$ is the maximum center tensile stress (MPa) and $P$ is the total load $(\mathrm{N})$ causing fracture,

$$
\begin{gathered}
X=(1+\nu) \ln \left[\left(\frac{B}{C}\right)^{2}\right]+\left(\frac{1-\nu}{2}\right)\left(\frac{B}{C}\right)^{2} \\
Y=(1+\nu)\left[1+\ln \left[\left(\frac{A}{C}\right)^{2}\right]\right]+(1-\nu)\left(\frac{A}{C}\right)^{2}
\end{gathered}
$$

where $v$ is Poisson's ration, 0.27; $A$ is the radius of the support circle $(\mathrm{mm}) ; B$ is the radius of the loaded area or pin tip (mm); $C$ is the radius of the specimen and $d$ is the specimen thickness at the point of fracture.

The microstructure of sintered HA and MnHA pellets was examined using a JEOL 6330F field emission scanning electron microscope (FESEM) operating at $5 \mathrm{kV}$. The fracture surface of sintered HA and MnHA pellets were sputter coated with gold palladium (SEM coating unit E5100, Polaron Instruments Inc., East Essex, UK) and used for microstructure analysis.

FESEM was also used to determine the grain size of HA pellets sintered over the temperature range of 1000 to $1300{ }^{\circ} \mathrm{C}$. FESEM was used since the average grain size of certain specimens were less than the resolution limit of optical microscopy. Sintered pellets were polished to a $1 \mu \mathrm{m}$ finish and then thermally etched for $30 \mathrm{~min}$ at $100{ }^{\circ} \mathrm{C}$ below the sintering temperature. The average grain size was determined from FESEM images using the line intercept method.

\section{Conclusions}

The sintering behavior of pure HA and MnHA was studied for the suitability of MnHA in load bearing applications. The maximum sintered density achieved for was 2.99 and 2.69 for HA and MnHA, respectively. Decomposition of $\mathrm{MnHA}$ into TCP and $\mathrm{Mn}_{3} \mathrm{O}_{4}$ occurred at $800{ }^{\circ} \mathrm{C}$, while $\mathrm{HA}$ pellets started to sinter at $900{ }^{\circ} \mathrm{C}$ with partial decomposition to $\beta$-TCP and CaO. The maximum M.O.R achieved for HA and MnHA were 78 and $64 \mathrm{MPa}$, respectively. The low thermal stability of MnHA suggests that a faster dissolution rate in vivo than pure HA is expected.

\section{Acknowledgments}

The authors would like to thank NSF grants (CBET-1133883 and CBET-1347130) and NSF GK-12 program (0947869) for their support. We extend our gratitude to Changmin $\mathrm{Hu}$ for her aid with TEM imaging. 


\section{Author Contributions}

Michael Zilm and Mei Wei conceived and designed the study. Michael Zilm and Seamus Thomson performed experiments. Michael Zilm and Mei Wei analyzed the data. All authors contributed to the writing of the paper.

\section{Conflicts of Interest}

The authors declare no conflict of interest.

\section{References}

1. Silverthorn, D.U. Human Physiology: An Integrated Approach, 5th ed.; Pearson Benjamin Cummings: San Francisco, CA, USA, 2010.

2. Bose, S.; Roy, M.; Bandyopadhyay, A. Recent advances in bone tissue engineering scaffolds. Trends Biotechnol. 2012, 30, 546-554. [CrossRef] [PubMed]

3. Murugan, R.; Ramakrishna, S. Bioresorbable composite bone paste using polysaccharide based nano hydroxyapatite. Biomaterials 2004, 25, 3829-3835. [CrossRef] [PubMed]

4. Chevalier, J.; Gremillard, L. Ceramics for medical applications: A picture for the next 20 years. J. Eur. Ceram. Soc. 2009, 29, 1245-1255. [CrossRef]

5. Woodard, J.R.; Hilldore, A.J.; Lan, S.K.; Park, C.J.; Morgan, A.W.; Eurell, J.A.C.; Clark, S.G.; Wheeler, M.B.; Jamison, R.D.; Johnson, A.J.W. The mechanical properties and osteoconductivity of hydroxyapatite bone scaffolds with multi-scale porosity. Biomaterials 2007, 28, 45-54. [CrossRef] [PubMed]

6. He, L.; Standard, O.C.; Huang, T.Y.; Latella, B.A.; Swain, M.V. Mechanical behaviour of porous hydroxyapatite. Acta Biomater. 2008, 4, 577-586. [CrossRef] [PubMed]

7. Ruys, A.J.; Wei, M.; Sorrell, C.G.; Dickson, M.R.; Brandwood, A.; Milthorpe, B.K. Sintering effects on the strength of hydroxyapatite. Biomaterials 1995, 6, 409-415. [CrossRef]

8. Kaur, G.; Pandey, O.P.; Singh, K.; Homa, D.; Scott, B.; Pickrell, G. A review of bioactive glasses: Their structure, properties, fabrication, and apatite formation. J. Biomed. Mater. Res. A 2014, 102, 254-274. [CrossRef] [PubMed]

9. Mostafa, N.Y. Characterisation, thermal stability and sintering of hydroxyapatite powders prepared by different routes. Mater. Chem. Phys. 2005, 94, 333-341. [CrossRef]

10. Guo, L.; Huang, M.; Zhang, X. Effects of sintering temperature on structure of hydroxyapatite studied with Rietveld method. J. Mater. Sci. Mater. Med. 2003, 14, 817-822. [CrossRef] [PubMed]

11. Vladescu, A.; Birlik, I.; Braic, V.; Toparli, M.; Celik, E.; Ak Azem, F. Enhancement of the mechanical properties of hydroxyapatite by SiC addition. J. Mech. Behav. Biomed. Mater. 2014, 40, 362-368. [CrossRef] [PubMed]

12. Mayer, I.; Jacobsohn, O.; Niazov, T.; Werckmann, J.; Iliescu, M.; Richard-Plouet, M.; Burghaus, O.; Reinen, D. Manganese in Precipitated Hydroxyapatite. Eur. J. Inorg. Chem. 2003, 7, 1445-1451. [CrossRef] 
13. Bigi, A.; Boanini, E.; Capuccini, C.; Gazzano, M. Strontium-substituted hydroxyapatite nanocrystals. Inorg. Chem. Acta. 2007, 360, 1009-1016. [CrossRef]

14. Medvecky, L.; Stulajterova, R.; Parilak, L.; Trpcevska, J.; Durisin, J.; Barinov, S.M. Influence of manganese on stability and particle growth of hydroxyapatite in simulated body fluid. Colloids Surf. A Physicochem. Eng. Asp. 2006, 291, 221-229. [CrossRef]

15. Aminzare, M.; Eskandari, A.; Baroonian, M.H.; Berenov, A.; Razavi Hesabi, Z.; Taheri, M.; Sadrnezhaad, S.K. Hydroxyapatite nanocomposites: Synthesis, sintering and mechanical properties. Ceram. Int. 2013, 39, 2197-2206. [CrossRef]

16. Oshida, Y. Hydroxyapatite: Synthesis and Applications; Momentum Press: New York, NY, USA, 2015.

17. Tarafder, S.; Balla, V.K.; Davies, N.M.; Bandyopadhyay, A.; Bose, S. Microwave-sintered 3D printed tricalcium phosphate scaffolds for bone tissue engineering. J. Tissue Eng. Regen. Med. 2013, 7, 631-641. [CrossRef] [PubMed]

18. Leventouri, T. Synthetic and biological hydroxyapatites: Crystal structure questions. Biomaterials 2006, 27, 3339-3342. [CrossRef] [PubMed]

19. Place, E.S.; Evans, N.D.; Stevens, M.M. Complexity in biomaterials for tissue engineering. Nat. Mater. 2009, 8, 457-470. [CrossRef] [PubMed]

20. Afshari, F.T.; Kwok, J.C.; Andrews, M.R.; Faissner, A.; Ffrench-Constant, C.; Fawcett, J.W. Integrin activation or alpha 9 expression allows retinal pigmented epithelial cell adhesion on Bruch's membrane in wet age-related macular degeneration. Brain 2010, 133, 448-464. [CrossRef] [PubMed]

21. Rabinovitch, M.; DeStefano, M.J. Manganese stimulates adhesion and spreading of mouse sarcoma I ascites cells. J. Cell Biol. 1973, 59, 165-176. [CrossRef] [PubMed]

22. Zhang, Z.; Gu, B.; Zhu, W.; Zhu, L. Integrin mediated osteoblastic adhesion on porous manganese-incorporated $\mathrm{TiO}_{2}$ coating prepared by plasma electrolytic oxidation. Exp. Ther. Med. 2013, 6, 707-714. [CrossRef] [PubMed]

23. Fujitani, W.; Hamada, Y.; Kawaguchi, N.; Mori, S.; Daito, K.; Uchinaka, A.; Matsumoto, T.; Kajima, Y.; Daito, M.; Nakano, T.; et al. Synthesis of hydroxyapatite containing manganese and its evaluation of biocompatibility. Nano Biomed. 2010, 2, 37-46.

24. Bigi, A.; Bracci, B.; Cuisiniere, F.; Elkaim, R.; Fini, M.; Mayer, I.; Mihailescu, I.N.; Socol, G.; Sturba, L.; Torricelli, P. Human osteoblast response to pulsed laser deposited calcium phosphate coatings. Biomaterials 2005, 26, 2381-2389. [CrossRef] [PubMed]

25. Erikson, K.M.; Syversen, T.; Aschner, J.L.; Aschner, M. Interactions between excessive manganese exposures and dietary iron-deficiency in neurodegeneration. Environ. Toxicol. Pharmacol. 2005, 19, 415-421. [CrossRef] [PubMed]

26. Baly, D.L.; Keen, C.L.; Hurley, L.C. Effects of manganese deficiency on pyruvate carboxylase and phosphoenolpyruvate carboxykinase activity and carbohydrate homeostasis in adult rats. Biol. Trace Element Res. 1986, 11, 201-212. [CrossRef] [PubMed]

27. Armulik, A.; Svineng, G.; Wennerberg, K.; Fassler, R.; Johansson, S. Expression of integrin subunit $\beta 1 \mathrm{~B}$ in integrin $\beta 1$-deficient GD25 cells does not interfere with $\alpha \mathrm{V} \beta 3$ functions. Exp. Cell Res. 2000, 254, 55-63. [CrossRef] [PubMed] 
28. Bracci, B.; Torricelli, P.; Panzavolta, S.; Boanini, E.; Giardino, R.; Bigi, A. Effect of $\mathrm{Mg}^{2+}, \mathrm{Sr}^{2+}$, and $\mathrm{Mn}^{2+}$ on the chemico-physical and in vitro biological properties of calcium phosphate biomimetic coatings. J. Inorg. Biochem. 2009, 103, 1666-1674. [CrossRef] [PubMed]

29. Golden, D.C.; Ming, D.W. Nutrient substituted hydroxyapatites: Synthesis and characterization. Soil Sci. Soc. Am. J. 1999, 63, 657-664. [CrossRef] [PubMed]

30. Sutter, B.; Wasowicz, T.; Howard, T.; Hossner, L.R.; Ming, D.W. Characterization of iron, manganese, and copper synthetic hydroxyapatites by electron paramagnetic resonance spectroscopy. Soil Sci. Soc. Am. J. 2002, 66, 1359-1366. [CrossRef] [PubMed]

31. Sutter, B.; Hossner, L.R.; Ming, D.W. Dissolution Kinetics of iron-, manganese-, and copper-containing synthetic hydroxyapatites. Soil Sci. Soc. Am. J. 2005, 69, 362-370. [CrossRef] [PubMed]

32. Sutter, B.; Ming, D.W.; Clearfield, A.; Hossner, L.R. Mineralogical and chemical characterization of iron-, manganese-, and copper-containing synthetic hydroxyapatites. Soil Sci. Soc. Am. J. 2003, 67, 1935-1942. [CrossRef] [PubMed]

33. Sutter, B.; Taylor, R.E.; Hossner, L.R.; Ming, D.W. Solid state ${ }^{31}$ phosphorous nuclear magnetic resonance of iron-, manganese-, and copper-containing synthetic hydroxyapatites. Soil Sci. Soc. Am. J. 2002, 66, 455-463. [CrossRef] [PubMed]

34. Mayer, I.; Cuisinier, F.J.G.; Popov, I.; Schleich, Y.; Gdalya, S.; Burghaus, O.; Reinen, D. Phase relations between $\beta$-tricalcium phosphate and hydroxyapatite with manganese (II): Structural and spectroscopic properties. Eur. J. Inorg. Chem. 2006, 2006, 1460-1465. [CrossRef]

35. Mayer, I.; Cuisinier, F.J.G.; Gdalya, S.; Popov, I. TEM study of the morphology of $\mathrm{Mn}^{2+}$ doped calcium hydroxyapatite and $\beta$-tricalcium phosphate. J. Inorg. Biochem. 2008, 102, 311-317. [CrossRef] [PubMed]

36. Paluszkiewicz, C.; Slosarczyk, A.; Pijocha, D.; Sitarz, M.; Bucko, M.; Zima, A.A.; Chroscicka, A.; Lewandowska-Szumiel, M. Synthesis, structural properties, and thermal stability of Mn-doped hydroxyapatite. J. Mol. Struct. 2010, 976, 301-309. [CrossRef]

37. Li, Y.; Nam, C.T.; Ooi, C.P. Iron (III) and manganese (II) substituted hydroxyapatite nanoparticles: Characterization and cytotoxicity analysis. J. Phys. Conf. Ser. 2009, 187. [CrossRef]

38. Li, Y.; Widodo, J.; Lim, S.; Ooi, C.P. Synthesis and cyctocompatability of managanese (II) and iron (III) substituted hydroxyapatite nanoparticles. J. Mater. Sci. 2012, 471, 754-763. [CrossRef]

39. Ramesh, S.; Tan, C.Y.; Peralta, C.L.; Teng, W.D. The effect of manganese oxide on the sinterability of hydroxyapatite. Sci. Technol. Adv. Mater. 2007, 8, 257-263. [CrossRef]

40. Muralithran, G.; Ramesh, S. The effects of sintering temperature on the properties of hydroxyapatite. Ceram. Int. 2000, 26, 221-230. [CrossRef]

41. Barinov, S.; Rau, J.; Nunziante Cesaro, S.; Durisin, J.; Fadeeva, I.; Ferro, D.; Medvecky, L.; Trionfetti, G. Carbonate release from carbonated hydroxyapatite in the wide temperature rage. J. Mater. Sci. Mater. Med. 2006, 17, 597-604. [CrossRef] [PubMed]

42. Zilm, M.E.; Staruch, M.; Jain, M.; Wei, M. An intrinsically magnetic biomaterial with tunable magnetic properties. J. Mater. Chem. B 2014, 2, 7176-7185. [CrossRef]

43. Gillot, B.; El Guendouzi, M.; Laarj, M. Particle size effects on the oxidation-reduction behavior of $\mathrm{Mn}_{3} \mathrm{O}_{4}$ hausmannite. Mater. Chem. Phys. 2001, 70, 54-60. [CrossRef] 
44. Carrodeguass, R.G.; de Aza, S. $\alpha$-Tricalcium phosphate: Synthesis, properties and biomedical applications. Acta Biomater. 2011, 7, 3536-3546. [CrossRef] [PubMed]

45. Wang, J.; Shaw, L. Morphology-enhanced low temperature sintering of nanocrystalline hydroxyapatite. Adv. Mater. 2007, 19, 2364-2369. [CrossRef]

46. Pattanayak, D.K.; Divya, P.; Upadyay, S.; Prasad, R.C.; Rao, B.T.; Rama Mohan, T.R. Synthesis and evaluation of hydroxyapatite ceramics. Trends Biomater. Artif. Organs 2005, 18, 87-92.

47. Pattanayak, D.K.; Dash, R.; Prasad, R.C.; Rao, B.T.; Rama Mahan, T.R. Synthesis and sintered properties evaluation of calcium phosphate ceramics. Mater. Sci. Eng. C 2007, 27, 654-690. [CrossRef]

48. Akao, M.; Aoki, H.; Kato, K. Mechanical properties of sintered hydroxyapatite for prosthetic applications. J. Mater. Sci. 1981, 16, 809-812. [CrossRef]

49. Pramanik, S.; Agarwal, A.K.; Rai, K.N.; Garg, A. Development of high strength hydroxyapatite by solid-state-sintering process. Ceram. Int. 2007, 33, 419-426. [CrossRef]

50. Sureshbabu, S.; Komath, M.; Varma, H.K. In situ formation of hydroxyapatite-alpha tricalcium phosphate biphasic ceramic with higher strength and bioactivity. J. Am. Ceram. Soc. 2012, 95, 915-924.

51. Kannan, S.; Vieira, S.I.; Olhero, S.M.; Torres, P.M.C.; da Cruz e Silva, O.A.B.; Ferreira, J.M.F.; Pina, S. Synthesis, mechanical and biological characterization of ionic doped carbonated hydroxyapatite/ß-tricalcium phosphate mixtures. Acta Biomater. 2011, 7, 1835-1843. [CrossRef] [PubMed]

52. Liu, H.S.; Chin, T.S.; Lai, L.S.; Chiu, S.Y.; Chung, K.H.; Chang, C.S.; Lui, M.T. Hydroxyapatite synthesized by a simplified hydrothermal method. Ceram. Int. 1997, 23, 19-25. [CrossRef]

53. Boilet, L.; Descamps, M.; Rguiti, E.; Tricoteaux, A.; Lu, J.; Petit, F.; Lardot, V.; Cambier, F.; Leriche, A. Processing and properties of transparent hydroxyapatite and B-tricalcium phosphate obtained by HIP process. Ceram. Int. 2013, 39, 283-288. [CrossRef]

54. Raynaud, S.; Champion, E.; Lafon, J.P.; Bernache-Assollant, D. Calcium phosphate apatites with variable $\mathrm{Ca} / \mathrm{P}$ atomic ratio III. Mechanical properties and degradation in solution of hot pressed ceramics. Biomaterials 2002, 23, 1081-1089. [CrossRef]

55. An, Y.H.; Draugh, R.A. Mechanical Testing of Bone and the Bone-Implant Interface; CRC Press: Boca Raton, FL, USA, 2000.

56. Wang, J.; Shaw, L. Nanocrystalline Hydroxyapatite with simultaneous enhancements in hardness and toughness. Biomaterials 2009, 30, 6565-6572. [CrossRef] [PubMed]

57. Kramer, E.; Zilm, M.; Wei, M. A Comparative study of the sintering behavior of pure and iron-substituted hydroxyapatite. Bioceram. Dev. Appl. 2013, 3. [CrossRef]

58. Yoshida, K.; Kondo, N.; Kita, H.; Mitamura, M.; Hashimoto, K.; Toda, Y. Effect of substitutional monovalent and divalent metal ions on mechanical properties of B-tricalcium phosphate. J. Am. Ceram. Soc. 2005, 88, 2315-2318. [CrossRef]

59. Tanimoto, Y.; Nishiyama, N. Preparation and physical properties of tricalcium phosphate laminates for bone tissue engineering. J. Biomed. Mater. Res. A 2008, 85, 427-433. [CrossRef] [PubMed] 
60. Seol, Y.J.; Park, J.Y.; Jung, J.W.; Jang, J.; Girdhari, R.; Kim, S.W.; Cho, D.W. Improvement of bone regeneration capability of ceramic scaffolds by accelerated release of their calcium ions. Tissue Eng. A 2014, 20, 2840-2849. [CrossRef] [PubMed]

61. ASTM Standard F 394 Test Method for Biaxial Flexure Strength (Modulus of Rupture) of Ceramic Substrates; ASTM International: West Conshohocken, PA, USA, 1996.

(C) 2015 by the authors; licensee MDPI, Basel, Switzerland. This article is an open access article distributed under the terms and conditions of the Creative Commons Attribution license (http://creativecommons.org/licenses/by/4.0/). 